ISSN: 2302-8556

\title{
Pengaruh Perputaran Modal Kerja dan Pertumbuhan Koperasi pada Profitabilitas dengan Non Performing LoanSebagai Moderasi
}

\author{
I Putu Pradiantama Risda Putra ${ }^{1}$ \\ Gede Juliarsa ${ }^{2}$ \\ ${ }^{1}$ Fakultas Ekonomi dan Bisnis Universitas Udayana (Unud), Bali, Indonesia \\ email: pradiantama.risda@yahoo.com/telp: 082237779942 \\ ${ }^{2}$ Fakultas Ekonomi dan Bisnis Universitas Udayana (Unud), Bali, Indonesia
}

\begin{abstract}
ABSTRAK
Koperasi adalah badan usaha yang berdasarkan atas asas kekeluargaan yang anggotanya terdiri dari orang perorangan atau badan hukum dengan tujuan untuk mensejahterakan anggotanya. Peran dan manfaat koperasi di Indonesia sangatlah penting, karena koperasi membuka pintu gerbang Usaha Kecil dan Menengah (UKM), menciptakan masyarakat mandiri, penggerak perekonomian hingga menciptakan lapangan kerja baru.Penelitian dilakukan pada Koperasi Simpan Pinjam di Kecamatan Denpasar Utara Tahun 2013-2015. Sampel penelitian ini adalah laporan keuangan masing-masing koperasi simpan pinjam yang ada di Kecamatan Denpasar Utara yang berjumlah 12 koperasi pada tahun 2013-2015 yang dipilih dengan metode nonprobability sampling dengan teknik purposive sampling. Pengujian data dilakukan dengan menggunakan Moderated Regression Analysis, hasilnya menunjukkan bahwa perputaran modal kerja dan pertumbuhan koperasi berpengaruh positifsignifikanpadaprofitabilitas. Penelitian ini jugamenemukanbahwaNon Performing Loan mampu memoderasi pengaruh perputaran modal kerjadan pertumbuhan koperasi pada profitabilitas.
\end{abstract}

Kata kunci: Tingkat perputaran modal kerja, pertumbuhan koperasi, profitabilitas, non performing loan.

\section{ABSTRACT}

Cooperative is a business entity based on the principle of kinship whose members consist of individuals or legal entities with the aim to welfare its members. Cooperatives open the gates of Small and Medium Enterprises, creating an independent community, driving the economy to create new jobs. The research was conducted on Savings and Loans Cooperative in North Denpasar Sub-Province of 2013-2015. The sample of this research is financial report of each existing savings and loan cooperative in North Denpasar Subdistrict which amounts to 12 cooperatives in 2013-2015 selected by nonprobability sampling method with purposive sampling technique. Testing data is done by using Moderated Regression Analysis, the result shows that the velocity of working capital and growth of cooperatives have a significant positive effect on profitability. This study also found that Non Performing Loan is able to moderate the effect of working capital turnover and cooperative growth on profitability.

Keywords: Rate of working capital turnover, cooperative growth, profitability, non performing loan.

\section{PENDAHULUAN}

Negara Indonesia memiliki pandangan yang khusus terhadap perekonomian, hal

ini termuat dalam UUD 1945 Bab XIV Pasal 33 ayat (1) yang menyebutkan 
I Putu Pradiantama Risda Putra danGede Juliarsa. Pengaruh...

bahwa "Perekonomian disusun sebagai usaha bersama berdasarkan atas azas kekeluargaan". Merujuk arti dari Pasal 33 ayat (1) UUD 1945, maka aturan tersebut paling tepat ditujukan terhadap koperasi. Definisi koperasi di Indonesia termuat dalam UU No. 25 tahun 1992 tentang perkoperasian yang menyebutkan bahwa koperasi adalah badan usaha yang beranggotakan orang-orang atau badan hukum koperasi dengan melandaskan kegiatannya berdasarkan prinsip koperasi, sekaligus sebagai gerakan ekonomi rakyat yang berdasarkan asas kekeluargaan.

Koperasi dianggap lembaga ekonomi dan sosial yang cocok untuk Indonesia sehingga sejak dulu sampai sekarang selalu menjadi obyek kebijakan pemerintah.Melalui koperasi pelaku ekonomi di masyarakat sama-sama diberdayakan (Sitio, 2001:167).Oleh karenanya koperasi mempunyai kedudukan, potensi dan peran yang strategis untuk mewujudkan struktur perekonomian nasional. Sehingga koperasi merupakan salah satu badan usaha yang dipilih oleh sebagian masyarakat dalam rangka meningkatkan taraf hidupnya.

Perusahaan tidak terkecuali koperasi dituntut untuk memiliki keunggulan kompetitif dan mampu meningkatkan kinerja yang dimilikinya serta mampu menghasilkan profit yang maksimal untuk menjamin kelangsungan hidup dan perkembangan usaha di masa yang akan datang. Kenyataannya banyak koperasi kesulitan mempertahankan eksistensinya, salah satunya karena manajemen koperasi belum professional.Leunupun (2003) mengungkapkan bahwa terkait dengan keputusan dalam hal pengelolaan penggunaan dana, maka pihak koperasi harus mampu mengalokasikan sumber daya keuangan yang dimiliki secara efisien 
serta menekan biaya-biaya penggunaan dana sehingga akan mampu meningkatkan laba atau Sisa Hasil Usaha (SHU) pada masa mendatang.

Pengelolaan berbagai aspek keuangan sebagai salah satu sumber daya strategis dalam menjalankan usaha memiliki dampak yang signifikan pada keberhasilan usaha sehingga perlu mendapat perhatian khusus. Keberhasilan pengelolaan keuangan dapat diukur melalui analisis terhadap laporan keuangan. Analisis laporan keuangan bermanfaat sebagai alat penilaian dan pengevaluasian apakah operasional koperasi berjalan secara ekonomis, efisien dan efektif sehingga dapat segera diambil tindakan strategis untuk mengoptimalkan profit dan memastikan koperasi terhindar dari kemungkinan bangkrut di masa depan.

Profitabilitas adalah kemampuan suatu perusahaan untuk memperoleh laba yang merupakan hasil akhir bersih dari kebijakan dan keputusan yang diambil perusahaan dalam suatu periode tertentu yang mencerminkan efektifitas manajemen (Prihadi, 2012). Munawir (2012:33) menjelaskan bahwa profitabilitas digunakan untuk mengukur efisiensi penggunaan modal dalam suatu perusahaan dengan membandingkan antara laba dengan modal yang digunakan dalam koperasi, oleh karena itu keuntungan yang besar tidak menjamin atau bukan merupakan ukuran bahwa perusahaan itu rentable. Koperasi yang mempunyai modal lebih besar lazimnya akan memperoleh laba yang besar pula dari pada koperasi yang mempunyai modal lebih sedikit. Ada beberapa faktor yang dapat mempengaruhi profitabilitas, salah satunya adalah perputaran modal kerja dan pertumbuhan koperasi. 
Modal kerja merupakan kekayaan atau aktiva yang diperlukan oleh koperasi untuk menyelenggarakan kegiatan operasional sehari-hari yang selalu berputar dalam periode tertentu (Dendawijaya, 2009:27). Felope dan Ajilore (2009) Working capitalmerupakan perputaran modal kerja dimulai pada saat kas yang diinvestasikan dalam komponen-komponen modal kerja sampai pada saat kembali lagi menjadi kas. Semakin pendek periode tersebut berarti semakin cepat perputaran modal kerja dan efisiensi penggunaan modal kerja perusahaan tinggi. Sebaliknya semakin panjang periode perputaran modal kerja berarti semakin lambat perputaran modal kerja dan efisiensi penggunaan modal kerja perusahaan rendah.

Pertumbuhan perusahaan (company growth) adalah peningkatan atau penurunan total aset yang dimiliki oleh perusahaan. Pertumbuhan perusahaan dihitung sebagai persentase perubahan aset pada periode sekarang dengan periode sebelumnya (Suprantiningrum, 2013). Pertumbuhan aset menggambarkan pertumbuhan aktiva perusahaan yang akan mempengaruhi profitabilitas perusahaan yang menyakini bahwa persentase perubahan total aktiva merupakan indikator yang lebih baik dalam mengukur pertumbuhan perusahaan (Putra, 2009). Beberapa penelitian telah dilakukan untuk menganalisis faktor-faktor yang dapat mempengaruhi profitabilitas yang hasil penelitiannya ada yang sejalan atau yang bertentangan. Penelitian-penelitian tersebut diantaranya dilakukan oleh Satrya dan Lestari (2014), Nopiana et al. (2015), Putri (2016) yang menunjukkan bahwa perputaran modal kerja berpengaruh signifikan terhadap profitabilitas. Penelitian mengenai pengaruh pertumbuhan aset terhadap profitabilitas juga telah 
dilakukan diantaranya oleh Yuliana (2014), Khaldun (2017), Kusumajaya (2011) dan Saraswathi (2016) yang menunjukkan bahwa pertumbuhan aset berpengaruh signifikan terhadap profitabilitas. Namun beberapa penelitian juga menunjukkan perputaran modal kerja dan pertumbuhan aset tidak berpengaruh signifikan terhadap profitabilitas. Penelitian yang dilakukan Nazir et al. (2009), Gamze et al. (2012) dan Santoso (2013) menyatakan modal kerja tidak berpengaruh signifikan terhadap profitabilitas perusahaan. Sunarto dan Agus (2009), Marchyta dan Dewi (2015), Damayanti dan Achyani (2006) dan Fitzsimons, et al.(2005) melakukan penelitian yang menunjukkan pertumbuhan aset tidak berpengaruh signifikan terhadap profitabilitas.

Terlihat terdapat ketidakkonsistenan hasil antara penelitian-penelitian yang telah dilakukan sebelumnya. Menurut Govindarajan (1986), untuk mengatasi ketidakkonsistenan hasil-hasil penelitian sebelumnya, maka diperlukan pendekatan kontijensi (contingency approach). Pendekatan kontijensi memungkinkan adanya variabel-variabel lain yang dapat bertindak sebagai pemoderasi yang mempengaruhi hubungan antara perputaran modal kerja dan pertumbuhan koperasi pada profitabilitas (Putri, 2016). Ketidakkonsistenan hasil antara penelitian-penelitian sebelumnya menjadi motivasi peneliti untuk melakukan penelitian kembali mengenai pengaruh perputaran modal kerja dan pertumbuhan koperasi pada profitabilitas dengan non performing loanyang diduga sebagai variabel moderasi.

Non Performing Loan merupakan rasio yang dipergunakan untuk mengukur kemampuan bank dalam mengkonversikan resiko kegagalan 
pengembalian kredit oleh debitur (Darmawan, 2004). Kegagalan pihak debitur untuk membayar angsuran pokok kredit beserta bunga yang telah disepakati kedua belah pihak dalam perjanjian kredit. Ferry dan Jones (1979) Semakin rendah persentase Non Performing Loan, maka perusahaan akan mengalami keuntungan, tetapi jika sebaliknya persentase Non Performing Loanyang semakin tinggi, maka bank tersebut mengalami kerugian. Bertambahnya biaya yang digunakan dalam pengelolaan kredit bermasalah akibat Non Performing Loanyang meningkat menyebabkan produktivitas bank menurun (Berger dan Mester, 2003).

Keberadaan koperasi di Denpasar cukup banyak namun banyak pula koperasi yang tidak aktif. Hal ini dikarena terlalu lama koperasi tidak melakukan aktivitasnya. Diskop UKMK mengusulkan kepada Kementerian Koperasi dan UKM untuk membekukan 103 koperasi yang tidak aktif. Namun, yang sudah keluar SK-nya, terdapat 79 unit koperasi dibekukan. Hal ini ditegaskan Kepala Dinas Koperasi UMKM Denpasar I Made Erwin Suryadarma Sena menyebutkan bahwa pemicu dilakukan pembekuan koperasi itu, salah satunya tidak pernah menggelar RAT selama tiga tahun berturut-turut. Selain itu, ada pula yang memang mengalami kebangkrutan.

Selain itu, Dinas Koperasi juga mengimbau kepada gerakan koperasi untuk segera melaksanakan RAT (Rapat Anggota Tahunan). Karena sesuai ketentuan, maksimal tiga bulan setelah tutup buku, maka koperasi wajib menggelar RAT sampai akhir Maret 2018. Ini merupakan amanat Undang-Undang Koperasi RI. Maksimal tiga bulan setelah tutup buku pada 31 Desember 2017 gerakan koperasi wajib melaksanakan RAT. Jumlah koperasi di Kota Denpasar sebanyak 1.128 
yakni 1.049 koperasi masih aktif. Sedangkan sisanya tidak aktif dan sudah diusulkan badan hukumnya dibekukan ke Kementerian Koperasi UKM karena tidak pernah menggelar RAT selama tiga tahun berturut-turut. Bahkan, ada koperasi sudah tidak beroperasi alias bangkrut.

Denpasar dipilih sebagai objek penelitian dikarenakan kota Denpasar merupakan kota dengan jumlah koperasi terbanyak dimana hal tersebut akan menimbulkan berbagai masalah dalam pelaksanaannya.Masih banyaknya koperasi di setiap kecamatan di Denpasar yang tidak melaksanakan Rapat Anggota Tahunan (RAT) merupakan permasalahan yang menyebabkan koperasi tersebut tidak sehat. Dari 4 kecamatan yang ada di Denpasar, Kecamatan Denpasar Utara merupakan kecamatan yang memiliki angka tidak RAT cukup tinggi, yaitu sebesar $71 \%$ dari 191 koperasi yang ada di Denpasar Utara.Berdasarkan data yang di dapatkan dari Dinas Koperasi UMK dan Menengah Kota Denpasar periode 2016, jumlah keseluruhan Koperasi di Kecamatan Denpasar Utara adalah sebanyak 191 koperasi. Dari 191 koperasi yang ada di Kecamatan Denpasar Utara sebanyak 181 koperasi aktif dan sebanyak 10 koperasi yang tidak aktif. Sebanyak 54 koperasi yang sudah melaksanakan RAT dan sebanyak 137 yang belum melaksanakan RAT. Gambaran koperasi aktif, tidak aktif dan RAT, tidak RAT berdasarkan jenis koperasi di Kecamatan Denpasar Utara dapat dilihat dalam Tabel 1. 
Tabel 1.

Koperasi Aktif, Tidak Aktif dan RAT, Tidak RAT berdasarkan Jenis Koperasi di Kecamatan Denpasar UtaraTahun 2016

\begin{tabular}{lccccc}
\hline Jenis Koperasi & Jumlah & Aktif & Tidak Aktif & RAT & Tidak RAT \\
\hline Koperasi Serba Usaha & 91 & 87 & 4 & 28 & 63 \\
Koperasi Simpan Pinjam & 54 & 51 & 3 & 12 & 42 \\
Koperasi Pasar & 2 & 2 & 0 & 1 & 1 \\
Koperasi Wanita & 1 & 1 & 0 & 0 & 1 \\
Koperasi Karyawan & 7 & 7 & 0 & 1 & 6 \\
Koperasi Usaha Dagang & 1 & 1 & 0 & 0 & 1 \\
Koperasi Jasa Angkutan & 1 & 1 & 0 & 0 & 1 \\
Umum & 34 & 31 & 3 & 12 & 22 \\
Lainnya & 191 & 181 & 10 & 54 & 137 \\
Jumlah & & & & &
\end{tabular}

Sumber: Data diolah, 2018

Dari tabel di atas, jenis koperasi di Kecamatan Denpasar Utarayang paling banyak adalah Koperasi Serba Usaha dan Koperasi Simpan Pinjam. Dari kedua koperasi tersebut, Koperasi Simpan Pinjam memiliki persentase Tidak RAT tertinggi, yaitu sebesar 78\%, sedangkan Koperasi Serba Usaha sebesar $69 \%$. Undang-undang No 25 tahun 1992 tentang penyelenggaraan RAT bahwa pelaksanaan RAT paling lambat 3 bulan sesudah tutup buku, sedangkan dari 54 Koperasi Simpan Pinjam sebanyak 42koperasi belum melaporkan RATnya dan ini tidak sesuai dengan Undang-Undang. Untuk itu peneliti tertarik meneliti Koperasi Simpan Pinjam karena diantara seluruh jenis koperasi di Denpasar Utara, Koperasi Simpan Pinjam memiliki persentase koperasi yang paling tinggi belum melaporkan RATnya.

Koperasi yang dapat mewujudkan kemakmuran rakyat melalui mensejahterakan anggotanya adalah koperasi yang mempunyai kemampuan finansial, kemampuan manajemen dan akan lebih baik lagi mampu memberikan fasilitas permodalan, untuk dapat mendorong anggotanya dalam meningkatkan usahanya atau membuka usaha baru, koperasi yang dapat memberikan hal itu 
adalah koperasi yang dalam status sehat.Semakin tinggi tingkat perputaran modal kerja dan pertumbuhan koperasi menunjukan profitabilitas yang tinggi dicapai oleh koperasi semakin tinggi pula tingkat efisiensi penggunaan modalnya. Semakin tinggi profitabilitas ekonomi maka potensi Sisa Hasil Usaha (SHU) yang diterima juga makin besar atau dengan kata lain SHU yang diterima dalam jumlah yang banyak. Mengingat pentingnya SHU ini, maka pengurus koperasi dituntut untuk mampu meningkatkan kerjanya untuk memperoleh laba.

Adapun penelitian ini bertujuan untuk: 1) Memberikan bukti empiris pengaruh perputaran modal kerja pada profitabilitas di Koperasi Simpan PinjamKecamatan Denpasar Utara tahun 2013-2015; 2) Memberikan bukti empiris pengaruh pertumbuhan koperasi pada profitabilitas di Koperasi Simpan PinjamKecamatan Denpasar Utara tahun 2013-2015; 3) Memberikan bukti empiris Non Performing Loan memoderasi pengaruh perputaran modal kerja pada profitabilitas di Koperasi Simpan Pinjam Kecamatan Denpasar Utara tahun 20132015; 4) Memberikan bukti empiris Non Performing Loan memoderasi pengaruh pertumbuhan koperasi pada profitabilitas di Koperasi Simpan Pinjam Kecamatan Denpasar Utara tahun 2013-2015.

Penelitianini memberikan bukti empiris tentang pengaruh perputaran modal kerja dan pertumbuhan koperasi pada profitabilitas Koperasi Simpan Pinjam di Kecamatan Denpasar Utara dengan Non Performing Loan(NPL) sebagai moderasi, serta penelitian ini juga mengonfirmasi beberapa teori terkait dengan pengaruh perputaran modal kerja dan pertumbuhan koperasi pada profitabilitas Koperasi Simpan Pinjam di Kecamatan Denpasar Utara dengan 
I Putu Pradiantama Risda Putra danGede Juliarsa. Pengaruh...

NPLsebagai moderasi.Teori sinyal menyatakan bahwa perusahaan yang berkualitas baik dengan sengaja akan memberikan sinyal pada pasar, dengan demikian pasar diharapkan dapat membedakan perusahaan yang berkualitas baik dan buruk. Agar sinyal tersebut baik maka harus ditangkap pasar dan dipersepsikan baik serta tidak mudah ditiru oleh perusahaan yang memiliki kualitas yang buruk.

Menurut Jama'an (2008) Signalling Theory mengemukakan tentang bagaimana seharusnya sebuah perusahaan memberikan sinyal kepada pengguna laporan keuangan. Teori sinyal menjelaskan bahwa pemberian sinyal dilakukan oleh manager untuk mengurangi asimetri informasi. Manager memberikan informasi melalui laporan keuangan bahwa mereka menerapkan kebijakan akuntansi konservatisme yang menghasilkan laba yang lebih berkualitas karena prinsip ini mencegah perusahaan melakukan tindakan membesar-besarkan laba dan membantu pengguna laporan keuangan dengan menyajikan laba dan aktiva yang tidak overstate.

Efisiensi modal kerja dapat dinilai dengan menggunakan rasio antara total pendapatan dengan jumlah modal kerja rata-rata yang sering disebut working capital turnover (perputaran modal kerja). Rasio ini menunjukkan hubungan antara modal kerja dengan pendapatan yang dapat diperoleh perusahaan untuk tiap rupiah modal kerja. Tingkat profitabilitas yang rendah bila dihubungkan dengan modal kerja dapat menunjukkan kemungkinan rendahnya volume pendapatan dibanding dengan ongkos yang digunakan (Arimbawa, 2017). Sehingga untuk 
menghindari itu, diharapkan adanya pengelolaan modal kerja yang tepat di dalam perusahaan.

Perusahaan yang dikatakan memiliki tingkat profitabilitas tinggi berarti tinggi pula efisiensi penggunaan modal kerja yang digunakan perusahaan tersebut. Hal ini sejalan dengan hasil penelitian Rajesh et al. (2011) yang menemukan perputaran modal kerja memiliki pengaruh signifikan terhadap profitabilitas. Penelitian Nopiana (2015) menyatakan tingkat perputaran modal kerja berpengaruh signifikan terhadap profitabilitas.Raheman dan Nasr (2007) menyatakan bahwa working capital turnover ratio berpengaruh signifikan terhadap tingkat profitabilitas.Narware (2004)berpendapat bahwa perputaran modal kerja berpengaruh signifikan terhadap profitabilitas. Berdasarkan uraian tersebut dapat ditarik hipotesis sebagai berikut.

$\mathrm{H}_{1}$ : Tingkat perputaran modal kerja berpengaruh positif pada profitabilitas.

Pertumbuhan menurut Mardiyah (2001) didefinisikan sebagai perubahan tahunan dari total aktiva. Pertumbuhan koperasi dapatdilihatdaripertumbuhan aset koperasi. Aset merupakan aktiva yang digunakan untuk aktivitas operasional perusahaan (Bambang, 2007). Pertumbuhan aset adalah perubahan (peningkatan atau penurunan) total aset yang dimiliki oleh koperasi.Pertumbuhan aset menggambarkan pertumbuhan aktiva perusahaan yang akan mempengaruhi profitabilitas perusahaan yang menyakini bahwa persentase perubahan total aktiva merupakan indikator yang lebih baik dalam mengukur growth perusahaan (Putra, 2009). 
Pertumbuhan aset yang baik akan memberisinyal kepada investor bahwa kinerja koperasi dalam keadaan yang baik pula. Dari sudut pandang investor, pertumbuhan aset memberikan sinyal positif dikarenakan koperasi dianggap mampu beroperasi dan mensejahterakan para anggotanya. Pertumbuhan aset menjadi indikator dari perolehan profitabilitas di koperasi. Dengan demikian pihak luar dengan mudah akan menanamkan modalnya dikarenakan melihat perkembangan atau pertumbuhan koperasi melalui profitabilitasnya. Hal ini menunjukan pengaruh yang positif antara pertumbuhan koperasi dengan profitabilitas koperasi. Hasil penelitian ini sejalan dengan penelitian Kusumajaya (2011), Kaptiana dan Asandimitra (2013), Memon et al. (2012) dan Kouser et al. (2012) menemukan bahwa pertumbuhan perusahaan memiliki pengaruh positif signifikan terhadap profitabilitas.

$\mathrm{H}_{2}$ : Tingkat pertumbuhan koperasi berpengaruh positif pada profitabilitas.

MenurutIriani (2013) menyatakan bahwa pengelolaan modal kerja yang efektif dan efisien akan menghasilkan nilai tambah dan keuntungan yang berkelanjutan, sedangkan kesalahan dalam pengelolaannya akan menyebabkan penurunan performa perusahaan yang akan berdampak pada penurunan profitabilitas. Optimalisasi modal kerja akan memberikan dampak positif terhadap profitabilitas koperasi. Menurut Satriya (2012) menjelaskan bahwa semakin tinggi perputaran kas dalam modal kerja maka keuntungan yang diperoleh perusahaan juga akan semakin tinggi. Bila keuntungan perusahaan semakin tinggi akan memberikan sinyal baik akan mendorong investor untuk menanamkan modalnya dalam koperasi. 
ISSN: 2302-8556

E-Jurnal Akuntansi Universitas Udayana

Vol.24.2.Agustus (2018): 820-844

Pembengkakan modal kerjaakanmengakibatkan kesulitan bagi perusahaan untuk meningkatkan profitabiltas (Pierre, 2010). NPL atau kredit bermasalah merupakan salah satu faktor yang dapat memperlemah pengaruh modal kerja pada profitabilitas. NPL didefinisikan sebagai pinjaman yang mengalami kesulitan pelunasan atau sering disebut kredit macet (Riyadi, 2006:161).NPL yang bertambah dalam koperasi dapat menurunkan kinerja koperasi sehingga membuat profitabilitas koperasi menurun. NPL menunjukan bahwa koperasi tidak professional dalam mengelola kredit sehingga mengalami kredit macet yang dapat berdampak pada penurunan profitabilitas.

$\mathrm{H}_{3}$ : Non Performing Loan memperlemah pengaruh perputaran modal kerja pada profitabilitas.

Pertumbuhan aset menunjukkan besarnya dana yang dialokasikan oleh perusahaan ke dalam asetnya (Susanto, 2016). Pertumbuhan aset mempunyai efek yang kuat terhadap nilai perusahaan terutama dalam perusahaan kecil dan menengah, karena dengan melihat investasi perusahaan atau kegiatan pembiayaan yang dilakukan, maka investor dapat memprediksi tingkat return yang akan didapatkan (Cooperet al. 2008). Hal tersebut juga berlaku dalam koperasi, pertumbuhan aset memberikan sinyal positif dikarenakan koperasi dianggap mampu beroperasi dan mensejahterakan para anggotanya. Pertumbuhan aset menjadi indikator dari perolehan profitabilitas di koperasi. Dengan demikian pihak luar dengan mudah akan menanamkan modalnya dikarenakan melihat perkembangan atau pertumbuhan koperasi melalui profitabilitasnya.

Besarnya persentase NPL haruslah menjadi perhatian pihak manajemen karena kredit bermasalah yang semakin meningkat dapat membahayakan 
kesehatan koperasi tersebut. Kredit yang disalurkan oleh koperasi memiliki risiko terjadinya gagal bayar oleh debitur.Pengaruh antara rasio kredit bermasalah terhadap profitabilitas, telah dibuktikan dengan penelitian Perkasa (2007) dan Rika (2008), yang menunjukkan hasil bahwa rasio kredit bermasalah berpengaruh negatif terhadap profitabilitas.

$\mathrm{H}_{4}$ : Non Performing Loan memperlemah pengaruh pertumbuhan koperasi pada profitabilitas.

\section{METODE PENELITIAN}

Pendekatan yang digunakan dalam penelitian ini adalah pendekatan kuantitatif berbentuk asosiatif. Penelitian ini dilakukan untuk mengetahui pengaruh variabel perputaran modal kerjadan pertumbuhan koperasi pada profitabilitas dengan non performing loan sebagai variabel moderasi. Desain penelitian ini disajikan dalam Gambar 1.

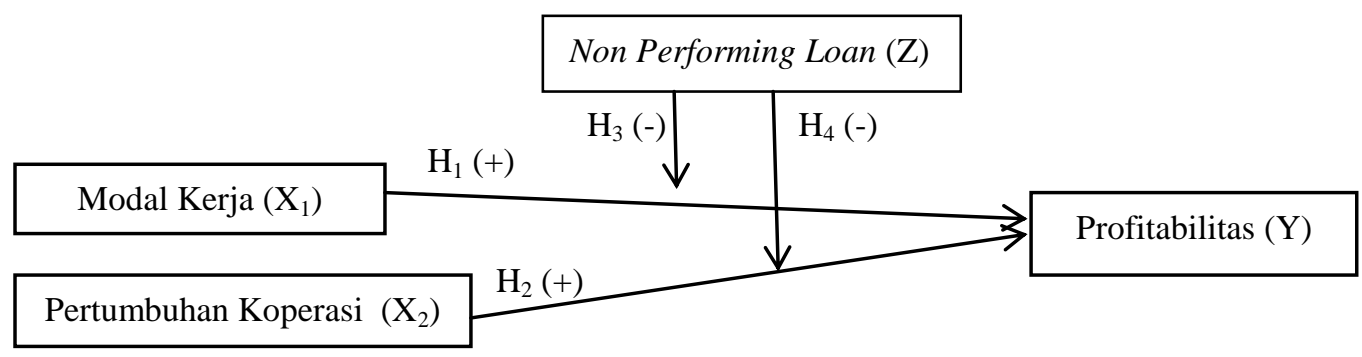

Gambar 1.

\section{Desain Penelitian}

Lokasi dari penelitian ini adalah Koperasi Simpan Pinjam yang ada di Kecamatan Denpasar Utara. Koperasi Simpan Pinjam di Kecamatan Denpasar Utara dipilih sebagai lokasi penelitian karena merupakan koperasi dengan jumlah terbanyak yang belum melakukan RAT hingga akhir bulan Maret.Objek penelitian yang menjadi kajian dalam penelitian ini adalah Profitabilitas Koperasi Simpan Pinjam di Kecamatan Denpasar Utara tahun 2013-2015 yang dipengaruhi oleh 
perputaran modal kerja dan pertumbuhan koperasi dengan non performing loan (NPL) sebagai moderasi.

Variabel independen (bebas) dalam penelitian ini adalah tingkat perputaran modal kerja $\left(\mathrm{X}_{1}\right)$ dan pertumbuhan koperasi $\left(\mathrm{X}_{2}\right)$.Variabel dependen dalam penelitian ini adalah profitabilitas (Y).Variabel moderasi dalam penelitian ini adalah non performing loan (Z).Jenis data yang digunakan dalam penelitian ini adalah data kuantitatif dan data kualitatif. Data kuantitatif yaitu data yang berupa angka-angka dan dapat dianalisis secara sistematis (Sugiyono, 2016) berupa laporan keuangan koperasi seperti, laporan laba rugi dan neraca Koperasi Simpan Pinjamdi Kecamatan Denpasar Utara. Data Kualitatif yaitu data yang dinyatakan dalam bentuk kata, kalimat dan gambar (Sugiyono, 2016). Data kualitatif dalam penelitian yang digunakan adalah gambaran umum struktur organisasi Koperasi Simpan Pinjam di Kecamatan Denpasar Utara.

Sumber data yang digunakan dalam penelitian ini adalah data sekunder. Data Sekunder merupakan sumber data yang tidak langsung memberikan data kepada pengumpul data, misalnya melalui orang lain atau lewat dokumen (Sugiyono, 2016). Dalam penelitian ini, data sekunder diperoleh dari Dinas Koperasi UMK dan Menengah Kota Denpasar. Metode pengumpulan data dalam penelitian ini adalah metode observasi non partisipan. Metode ini dilakukan dengan mencatat atau mengumpulkan data-data yang tersedia di Dinas Koperasi UMK dan Menengah Kota Denpasar.

Populasi dari penelitian ini adalah seluruh koperasi simpan pinjam yang ada di Kecamatan Denpasar Utara, sebanyak 54 koperasi. Karena koperasi simpan 
pinjam yang paling banyak belum melaksanakan RAT, dan ini tidak sesuai dengan Undang-undang No. 25 Tahun 1992 tentang penyelenggaraan RAT bahwa pelaksanaan RAT paling lambat 3 bulan sesudah tutup buku.Sampel yang digunakan adalah Koperasi Simpan Pinjam yang ada di Kecamatan Denpasar Utara dan telah melaksanakan RAT.

Teknik penentuan sampel yang digunakan dalam penelitian ini adalah teknik purposive sampling yang diambil berdasarkan kriteria-kriteria yang dirumuskan terlebih dahulu oleh peneliti. Dari 54 Koperasi Simpan Pinjam di Kecamatan Denpasar Utara, diperoleh 12 Koperasi Simpan Pinjam yang memenuhi kriteria untuk menjadi sampel penelitian ini. Kriteria yang dipilih adalah sebagai berikut:1) Koperasi terdaftar di Dinas Koperasi, UMK dan Menengah Kota Denpasar; 2) Hanya 12 koperasi simpan pinjam yang sudah melaporkan RAT dan ini sudah sesuai dengan Undang-undang No. 25 Tahun 1992 yang artinya koperasi tersebut sudah mengesahkan laporan keuangannya yang nantinya akan digunakan sebagai dasar penelitian yang kemudian dikali 3 untuk tiap tahun pengamatan, sehingga terdapat 36 pengamatan.3) Laporan keuangan yang dilaporkan lengkap.

Pada penelitian ini teknik analisis regresi yang digunakan adalah Moderated Regression Analysis (MRA). Analisis MRA digunakan untuk menjelaskan variabel pemoderasi dapatkah menjadi pemoderasi dan pemoderasi tersebut apakah memperkuat atau memperlemah hubungan antara variabel independen dan dependen.Persamaan regresi yang dapat disusun sebagai berikut: 
$\mathrm{Y}=\alpha+\beta_{1} \mathrm{X}_{1}+\beta_{2} \mathrm{X}_{2}+\beta_{3} \mathrm{Z}+\beta_{4} \mathrm{X}_{1} * \mathrm{Z}+\beta_{5} \mathrm{X}_{2} * \mathrm{Z}+\mathrm{e}$

Keterangan :

Y : Profitabilitas

$\alpha \quad$ : Konstanta

$\beta_{1,-} \beta_{5} \quad$ : Koefisien Regresi

$\mathrm{X}_{1} \quad$ : Perputaran Modal Kerja

$\mathrm{X}_{2} \quad$ : Pertumbuhan Koperasi

$\mathrm{Z} \quad$ : Non Performing Loan

e : Error

\section{HASIL DAN PEMBAHASAN}

Analisis statistik deskriptif dilakukan untuk memberikan gambaran atau deskripsi mengenai variabel penelitian melalui nilai rata-rata (mean), nilai minimum, nilai maksimum, dan standar deviasi.Hasil dari analisis statistik deskriptif dari variabel modal kerja $\left(\mathrm{X}_{1}\right)$, pertumbuhan koperasi $\left(\mathrm{X}_{2}\right)$, NPL $\left(\mathrm{Z}_{1}\right)$, profitabilitas $(\mathrm{Y})$ dapat dilihat pada Tabel 2 .

Tabel 2.

Statistik Deskriptif

\begin{tabular}{lccccc}
\hline & $\mathbf{N}$ & Minimum & Maximum & Mean & Std. Deviation \\
\hline Tingkat Perputaran & 36 & .22 & 9.26 & 1.5328 & 2.28242 \\
Modal Kerja & & & & & \\
Tingkat Pertumbuhan & 36 & -.01 & .90 & .1550 & .16439 \\
Koperasi & & & & & \\
NPL & 36 & .01 & .13 & .0572 & .02614 \\
Profit & 36 & .01 & .12 & .0717 & .02903 \\
Valid N (listwise) & 36 & & & & \\
Sumber: Data diolah, 2018 & & & & &
\end{tabular}

Berdasarkan Tabel 2. dapat dilihat hasil statistik masing-masing variabel, yang selanjutnya dapat diuraikan deskripsi dari masing-masing variabel. Dari hasil pengujian statistik deskriptif, variabel perputaran modal kerja $\left(\mathrm{X}_{1}\right)$ memiliki nilai terendah (minimum) sebesar 0,22 yang dimiliki oleh KSP. Dana Sari pada tahun 2015, sedangkan nilai tertinggi (maksimum) sebesar 9,26 yang dimiliki oleh adalah KSP. Merta Sari Buanapada tahun 2014, dengan rata-rata (mean) sebesar 1,5328 dan standar deviasi sebesar 2,28224. Nilai rata-rata sebesar 1,5328 berarti, 
I Putu Pradiantama Risda Putra danGede Juliarsa. Pengaruh...

dari setiap Rp 10.000,- modal kerja neto, koperasi mampu menghasilkan 1,53 rupiah pendapatan.

Variabel pertumbuhan koperasi $\left(\mathrm{X}_{2}\right)$ memiliki nilai terendah (minimum) sebesar -0,01 yang dimiliki oleh KSP. Merta Sari Buana pada tahun 2014 sedangkan nilai tertinggi (maksimum) sebesar 0,90 yang diiliki oleh KSP. Semeton Masyarakat Anak Rantau Tabanan pada tahun 2013, dengan rata-rata (mean) sebesar 0,1550 dan standar deviasi sebesar 0,16439. Nilai rata-rata sebesar 0,1550 berarti, rata-rata pertumbuhan koperasi tumbuh sebesar 0,155 dari tahun sebelumnya selama 3 tahun berturut-turut.

Variabel NPL (Z) memiliki nilai terendah (minimum) sebesar 0,01 yang dimiliki oleh KSP. Merta Sari Buana pada tahun 2013-2015 sedangkan nilai tertinggi (maksimum) sebesar 0,13 yang dimiliki oleh KSP. Karya Mulia Mandiri pada tahun 2015, dengan rata-rata (mean) sebesar 0,0572 dan standar deviasi sebesar 0,02614. Nilai rata-rata sebesar 0,0572 berarti, rata-rata npl sebesar 0,05 artinya dari setiap $\mathrm{Rp} 10.000$,- kredit yang disalurkan terdapat $\mathrm{Rp} 572$,- kredit yang bermasalah.

Variabel profitabilitas memiliki nilai terendah (minimum) sebesar 0,01 yang dimiliki oleh KSP. Merta Sari Buana pada tahun 2014 sedangkan nilai tertinggi (maksimum) sebesar 0,12 yang dimiliki oleh KSP. Cipta Sedana pada tahun 2013, dengan rata-rata (mean) sebesar 0,0717 dan standar deviasi sebesar 0,02903. Nilai rata-rata sebesar 0,0717 berarti, setiap penggunaan Rp 10.000,aktiva untuk aktivitas bisnis, koperasi mampu menghasilkan laba bersih sejumlah $\operatorname{Rp} 717$. 
Uji asumsi klasik dilakukan dengan tujuan untuk memastikan hasil yang diperoleh memenuhi asumsi dasar di dalam analisis regresi. Uji normalitas bertujuan untuk menguji apakah dalam model regresi, data variabel mempunyai distribusi normal atau tidak normal. Model regresi yang baik adalah model dengan data variabel yang terdistribusi normal (Utama, 2011:99). Berdasarkan hasil uji normalitas pada penelitian ini menunjukkan bahwa nilai Asymp. Sig (2-tailed) variabel perputaran modal kerja sebesar 20,0\% lebih besar dari level of significant, yaitu 5 persen $(0,05)$, nilai Sig (2-tailed) variabel pertumbuhan koperasi sebesar $79,4 \%$ lebih besar dari level of significant, yaitu 5 persen $(0,05)$, nilai Sig (2tailed) variabel NPL sebesar 64,4\% lebih besar dari level of significant, yaitu 5 persen $(0,05)$, dan nilai Sig (2-tailed)variabel profitabilitas sebesar 61,6\% lebih besar dari level of significant, yaitu 5 persen $(0,05)$, maka dapat disimpulkan seluruh data berdistribusi normal.

Suatu model regresi jika mengandung gejala autokorelasi, maka prediksi yang dilakukan dengan model tersebut akan tidak baik, atau dapat memberikan hasil prediksi yang menyimpang.Hasil uji autokorelasi pada penelitian ini menunjukkan nilai DW 1,877, nilai ini bila dibandingkan dengan nilai tabel signifikansi 5\%, jumlah sampel 36 (n) dan jumlah variabel independen $(K=5)$ maka diperoleh nilai du 1,787. Nilai DW 1,877 lebih besar dari batas atas (du) yakni 1,787 dan kurang dari (4-du) 4-1,787 = 2,213, maka dapat disimpulkan bahwa tidak terdapat autokorelasi.

Uji heteroskedastisitas bertujuan untuk mengetahui apakah dalam model regresi terjadi ketidaksamaan varians dari residual satu pengamatan ke 
pengamatan lain yang dilakukan dengan uji Glejser. Hasil uji heteroskedastisitas pada penelitian ini menunjukkan bahwa nilai Sig. dari variabel perputaran modal kerja sebesar 0,994, pertumbuhan koperasi sebesar 0,197, NPL sebesar 0,626, variabel interaksi $X_{1} . Z$ sebesar 0,148 dan variabel interaksi $X_{2} . Z$ sebesar 0,979 . Nilai tersebut lebih besar dari 0,05 yang berarti tidak terdapat pengaruh antara variabel bebas terhadap absolute residual. Dengan demikian, model yang dibuat tidak mengandung gejala heteroskedastisitas. Berdasarkan hasil uji normalitas, uji autokorelasi dan uji heteroskedastisitas yang telah dilakukan, maka dapat dinyatakan model regresi penelitian ini telah lolos uji asumsi klasik.

Penelitian ini menggunakan model Moderated Regression Analysis (MRA) untuk mengetahui hubungan antara pengaruh perputaran modal kerja dan pertumbuhan koperasi pada profitabilitas dengan Non Performing Loan sebagai moderasi dengan bantuan komputer Statistical Package of Social Science (SPSS).

Tabel 3.

Hasil Analisis Regresi Moderasi

\begin{tabular}{|c|c|c|c|c|c|}
\hline \multirow{2}{*}{ Variabel } & \multicolumn{2}{|c|}{$\begin{array}{l}\text { Unstandardized } \\
\text { Coefficients }\end{array}$} & \multirow{2}{*}{$\begin{array}{c}\begin{array}{c}\text { Standardized } \\
\text { Coefficients }\end{array} \\
\text { Beta }\end{array}$} & \multirow{2}{*}{ Sig. } & \multirow{2}{*}{$\begin{array}{l}\text { Hasil Uji } \\
\text { Hipotesis }\end{array}$} \\
\hline & B & $\begin{array}{c}\text { Std. } \\
\text { Error }\end{array}$ & & & \\
\hline (Constant) & .055 & .079 & & .496 & \\
\hline $\begin{array}{l}\text { Perputaran Modal } \\
\text { Keria }\end{array}$ & .237 & .080 & .245 & .006 & $\mathrm{H}_{1}$ diterima \\
\hline $\begin{array}{l}\text { Rerja } \\
\text { Pertumbuhan Koperasi }\end{array}$ & .221 & .092 & .210 & .022 & $\mathrm{H}_{2}$ diterima \\
\hline NPL & .149 & .090 & .148 & .110 & \\
\hline Interaksi $\mathrm{X}_{1} \cdot \mathrm{Z}$ & .470 & .099 & .439 & .000 & $\mathrm{H}_{3}$ ditolak \\
\hline Interaksi $\mathrm{X}_{2} . \mathrm{Z}$ & .172 & .080 & .199 & .039 & $\mathrm{H}_{4}$ ditolak \\
\hline Adjusted R Square & & & & & 0,829 \\
\hline Signifikansi $F_{\text {hitung }}$ & & & & & 0,000 \\
\hline
\end{tabular}

Berdasarkan hasil analisis regresi moderasi yang diperoleh, nilai konstanta sebesar 0,055menyatakan bahwa jika variabel independen dianggap konstan, maka nilai profitabilitas yang diproksikan dengan Return on Asets (ROA) sebesar 
0,055. Dari persamaan regresi tersebut, dapat dilihat bahwa nilai beta dari rasio perputaran modal kerja bertanda positif yaitu sebesar 0,237menunjukan bahwabila perputaran modal kerja naik satu satuan, maka ROA akan mengalami peningkatan sebesar 0,237 satuan, dengan asumsi variabel independen lainnya konstan.

Nilai beta dari rasio pertumbuhan koperasi bertanda positif yaitu sebesar 0,221 menunjukan bahwa bila pertumbuhan koperasi naik satu satuan, maka ROA akan mengalami peningkatan sebesar 0,221 satuan, dengan asumsi variabel independen lainnya konstan.Nilai beta dari rasio Non Performing Loan bertanda positif yaitu 0,149 menunjukan bahwa Non Performing Loan naik satu satuan, maka ROA akan mengalami peningkatan sebesar 0,149 satuan, dengan asumsi variabel independen lainnya konstan

Nilai beta dari interaksi antara variabel perputaran modal kerja dengan variabel rasio Non Performing Loan bertanda positif yaitu sebesar 0,470 menunjukan bahwa bila interaksi antara variabel perputaran modal kerja dan variabel rasio Non Performing Loan naik satu satuan, maka ROA akan mengalami peningkatan sebesar 0,470 satuan, dengan asumsi variabel independen lainnya konstan.Nilai beta dari interaksi antara variabel pertumbuhan koperasi dengan variabel rasio Non Performing Loan bertanda positifyaitu sebesar 0,172 menunjukan bahwa bila interaksi antara variabel pertumbuhan koperasi dan variabel rasio Non Performing Loan naik satu satuan maka, ROA akan mengalami peningkatan sebesar 0,172 satuan, dengan asumsi variabel independen lainnya konstan. 
Analisis koefisien determinasi digunakan untukmengetahui dan mengukur kemampuan model dalam menerangkan variasi variabel independen digunakan koefisien determinasi $\left(\mathrm{R}^{2}\right)$. Nilai adjusted $\mathrm{R}^{2}$ yang disajikan pada Tabel 3. adalah sebesar 0,829. Ini berarti variasi profitabilitas di Koperasi Simpan Pinjam Kecamatan Denpasar Utara tahun 2013-2015 dapat dijelaskanoleh variabel perputaran modal kerja $\left(\mathrm{X}_{1}\right)$, pertumbuhan koperasi $\left(\mathrm{X}_{2}\right)$, dan non performing loan (Z), sebesar $82,9 \%$ sedangkan sisanya sebesar $17,1 \%$ dijelaskan oleh variabel lain diluar model regresi yang digunakan.

Uji kelayakan model (Uji F) bertujuan untuk mengetahui apakah model regresi yang diestimasi layak atau tidak. Berdasarkan hasil uji kelayakan model pada penelitian ini diperoleh nilai antar kelompok pembanding $=5$, nilai dalam kelompok penyebut $=30$, pada alfa $=0,05$ maka nilai $\mathrm{F}$ tabelnya adalah F0,05(5,30) $=2,53$ Sedang F hitung $=35,027$. Nilai Fhitung $>$ Ftabel, 35,027 > 2,53 dengan nilai signifikansi $0,000<0,05$. Maka $\mathrm{H}_{0}$ ditolak pada taraf nyata 0,05 $\left(\mathrm{H}_{1}\right.$ diterima). Kesimpulannya, pada kelompok yang diuji memiliki perbedaan yang nyata (signifikan) berarti bahwa Perputaran Modal Kerja, Pertumbuhan Koperasi, Non Performing Loan (NPL), interaksi antara Perputaran Modal Kerja dengan Non Performing Loan (NPL), dan interaksi antara Pertumbuhan Koperasi dengan Non Performing Loan (NPL) secara simultan berpengaruh signifikan padaProfitabilitas.

Berdasarkan hasil analisis pengaruh modal kerja pada profitabilitas diperoleh nilai signifikansi sebesar 0,006 dengan nilai koefisien regresi sebesar 0,237. Nilai signifikansi 0,006 lebih besar dari 0,05 hal ini menunjukkan bahwa 
perputaran modal kerja memiliki pengaruh positif terhadap profitabilitas. Dengan demikian, hipotesis pertama $\left(\mathrm{H}_{1}\right)$ diterima yang menyatakan bahwa perputaran modal kerja berpengaruh positif pada profitabilitas. Hasil penelitian ini menunjukkan bahwa semakin tingginya perputaran modal kerja perusahaan mengakibatkan semakin besarnya tingkat profitabilitas koperasi. Ini mengindikasikan bahwa penggunaan modal kerja yang sudah efisien akan mengakibatkan peningkatan jumlah profitabilitas koperasi.

Riyanto (2011) menyatakan bahwa tingkat perputaran modal kerja menunjukkan efektifitas penggunaan modal kerja dalam perusahaan karena semakin tinggi tingkat perputaran modal kerja semakin efektif penggunaan modal kerja. Semakin cepat modal kerja berputar maka semakin besar keuntungan yang dapat diraih suatu perusahaan untuk meningkatkan profitabilitas.Hal ini menunjukan pengaruh yang positif antara perputaran modal kerja dengan profitabilitas koperasi. Hasil penelitian ini sejalan dengan hasil penelitian Narware (2004), Rajesh et al. (2011),Nopiana (2015) dan Raheman dan Nasr (2007) yang menemukan bahwa perputaran modal kerja memiliki pengaruh positif signifikan terhadap profitabilitas.

Berdasarkan hasil analisis pengaruh pertumbuhan koperasi pada profitabilitas diperoleh nilai signifikansi sebesar 0,022 dengan nilai koefisien regresi sebesar 0,221. Nilai signifikansi 0,022 lebih kecil dari 0,05 hal ini menunjukkan bahwa pertumbuhan koperasi memiliki pengaruh positif terhadap profitabilitas. Dengan demikian, hipotesis kedua $\left(\mathrm{H}_{2}\right)$ diterima yang menyatakan bahwa pertumbuhan koperasi berpengaruh positif pada profitabilitas. Hasil 
I Putu Pradiantama Risda Putra danGede Juliarsa. Pengaruh...

penelitian ini menunjukkan pertumbuhan aset menggambarkan pertumbuhan aktiva perusahaan yang akan mempengaruhi profitabilitas perusahaan yang menyakini bahwa persentase perubahan total aktiva merupakan indikator yang lebih baik dalam mengukur growth perusahaan (Putra, 2009).

Pertumbuhan aset yang baikakanmemberisinyalkepada investor bahwa kinerja koperasi dalam keadaan yang baik pula. Dari sudutpandang investor, pertumbuhan aset memberikan sinyal positif dikarenakan koperasi dianggap mampu beroperasi dan mensejahterakan para anggotanya. Pertumbuhan aset menjadi indikator dari perolehan profitabilitas di koperasi. Dengan demikian pihak luar dengan mudah akan menanamkan modalnya dikarenakan melihat perkembangan atau pertumbuhan koperasi melalui profitabilitasnya. Hal ini menunjukan pengaruh yang positif antara pertumbuhan koperasi dengan profitabilitas koperasi. Hasil penelitian ini sejalan dengan penelitian Kusumajaya (2011), Kaptiana dan Asandimitra (2013), Memon et al. (2012) dan Kouser et al. (2012) menemukan bahwa pertumbuhan perusahaan memiliki pengaruh positif signifikan terhadap profitabilitas.

Berdasarkan hasil analisis pengaruh modal kerja pada profitabilitas diperoleh nilai signifikansi sebesar 0,000 dengan nilai koefisien regresi sebesar 0,470. Nilai signifikansi 0,000 lebih kecil dari 0,05 hal ini menunjukkan bahwa NPL dapat memoderasi dan memperkuat hubungan antara perputaran modal kerja pada profitabilitas. Dengan demikian, hipotesis ketiga $\left(\mathrm{H}_{3}\right)$ ditolak yang menyatakan bahwa NPL memoderasi memperlemah pengaruh perputaran modal kerja pada profitabilitas. Pengelolaan modal kerja yang efektif dan efisien akan 
menghasilkan nilai tambah dan keuntungan yang berkelanjutan, sedangkan kesalahan dalam pengelolaannya akan menyebabkan penurunan performa perusahaan yang akan berdampak pada penurunan profitabilitas (Iriani 2013). Optimalisasi modal kerja akan memberikan dampak positif terhadap profitabilitas koperasi. Menurut Satriya (2012) menjelaskan bahwa semakin tinggi perputaran kas dalam modal kerja maka keuntungan yang diperoleh perusahaan juga akan semakin tinggi.

Kemampuan manajemen koperasi dalam mengelola kredit bermasalah untuk menghasilkan pendapatan bunga bersih dapat dilihat melalui NPL. Jadi, semakin baik manajemen dalam mengelola kredit bermasalah maka profitabilitasnya akan semakin meningkat (Pratiwi dan Wiagustini, 2015). Hasil penelitian menunjukkan kecilnya dampak NPL pada profitabilitas didugakarena NPL yang terjadi pada sebagian besar koperasi di Denpasar Utarakurang dari 5 persen yang menunjukkan bahwa koperasi tersebut mengalami risikokredit yang rendah, sehingga membuat NPL berpengaruh memperkuat padaprofitabilitas. Rendah disini dimaksudkan bahwa NPL dalam koperasi tidaklah selamanya berdampak buruk pada koperasi namun dapat meningkatkan profitabilitas serta modal kerja melalui jaminan kredit yang diberikan. Ini pula berarti bila NPLmeningkat maka hubungan perputaran modal kerja pada profitabilitas juga akan meningkat pula.

Penelitian ini bertentangan dengan penelitian yang dilakukan oleh Dewi (2015) yang menyatakan bahwa NPL berpengaruh negatif terhadap profitabilitas. Penelitian inisejalan dengan penelitian yangdilakukan oleh Fajari (2017), Pratiwi 
I Putu Pradiantama Risda Putra danGede Juliarsa. Pengaruh...

dan Wiagustini (2015) dan Dasih (2014), yang menunjukkan bahwa Non Performing Loan (NPL) berpengaruh positif terhadap profitabilitas. Narware (2004),Rajesh et al. (2011), Nopiana (2015) dan Raheman dan Nasr (2007) yang menemukan bahwa perputaran modal kerja memiliki pengaruh positif signifikan terhadap profitabilitas.

Berdasarkan hasil analisis pengaruh pertumbuhan koperasi pada profitabilitas diperoleh nilai signifikansi sebesar 0,039 dengan nilai koefisien regresi sebesar 0,172. Nilai signifikansi 0,039 lebih kecil dari 0,05 hal ini menunjukkan bahwa NPL dapat memoderasi dan memperkuat hubungan antara pertumbuhan koperasi pada profitabilitas. Dengan demikian, hipotesis keempat $\left(\mathrm{H}_{4}\right)$ ditolak yang menyatakan bahwa NPL memoderasi memperlemah pengaruh pertumbuhan koperasi pada profitabilitas.

Pertumbuhan koperasi dapat dinilai melalui pertumbuhan aset perusahaan. Pertumbuhan aset memberikan sinyal positif dikarenakan koperasi dianggap mampu beroperasi dan mensejahterakan para anggotanya. Pertumbuhan aset menjadi indikator dari perolehan profitabilitas di koperasi. Besarnya persentase NPL haruslah menjadi perhatian pihak manajemen karena kredit bermasalah yang semakin meningkat dapat membahayakan kesehatan koperasi tersebut. Nilai NPL pada koperasi di Denpasar Utara menunjukkan nilai kurangdari 5 persen yang menunjukkan bahwa koperasi tersebut mengalami risikokredit yang rendah. Hal tersebut menandakan bahwa kredit bermasalah yang ada di koperasi tidaklah membahayakan kesehatan koperasi. Kredit macet yang disalurkan oleh koperasi dapat memiliki risiko terjadinya gagal bayar oleh debitur namun dapat ditutupi 
melalui jaminan kredit yang diberikan oleh debitur. Profitabilitas pun dapat meningkat dengan keadaan NPL yang memiliki risiko rendah. Hal ini berarti bahwa NPL dapat memperkuat hubungan pertumbuhan koperasi pada profitabilitas.

Hasil penelitian inimendukung hasil penelitian serupa yangdilakukan oleh Fajari (2017), Pratiwi dan Wiagustini (2015) dan Dasih (2014)yangmenunjukkan bahwa Non Performing Loan(NPL) berpengaruh positif terhadapprofitabilitas. Kusumajaya (2011), Kaptiana dan Asandimitra (2013), Memon et al. (2012) dan Kouser et al. (2012) menemukan bahwa pertumbuhan perusahaan memiliki pengaruh positif signifikan terhadap profitabilitas.

\section{SIMPULAN}

Berdasarkan hasil analisis data dan pembahasan, maka simpulan penelitian ini yaitu: 1) Tingkat perputaran modal kerja berpengaruh positif signifikan pada profitabilitas; 2) Tingkat pertumbuhan koperasi berpengaruh positif signifikan pada profitabilitas; 3) Non Performing Loan mampu memoderasi dan memperkuat hubungan antara perputaran modal kerja pada profitabilitas; 4) Non Performing Loan mampu memoderasi dan memperkuat hubungan antara pertumbuhan koperasi pada profitabilitas.

Bagi penelitian selanjutnya disarankan dapat menggunakan jenis koperasi yang lain seperti Koperasi Serba Usaha dan lain-lain dengan wilayah penelitian yang berbeda sehingga diperoleh hasil yang lebih variatif. Peneliti selanjutnya juga disarankan menggunakan variabel bebas atau moderasi lainnya, misalnya 
I Putu Pradiantama Risda Putra danGede Juliarsa. Pengaruh...

loan to deposit ratio dan intellectual capital, karena faktor-faktor tersebut merupakan hal-hal yang berfaedah bagi kelangsungan koperasi.

\section{REFERENSI}

Arimbawa, I Komang Tirta. 2017. Pengaruh Tingkat Perputaran Aktiva Lancar, Perputaran Modal Kerja, Likuiditas, Ukuran Perusahaan dan Pertumbuhan Koperasi terhadap Profitabilitas. Skripsi. Fakultas Ekonomi dan Bisnis Universitas Udayana.

Damayanti, S dan F. Achyani, 2006. Analisis Pengaruh Investas, Likuiditas, Profitabilitas, Pertumbuhan Perusahaan dan Ukuran Perusahaan terhadapKebijakan Deviden Payout Ratio, Jurnal Akuntansi dan Keuangan, 5(4) hal: 51-62.

Darmawan, Komang. 2004. Analisis Rasio-Rasio Bank. Info Bank. 18-21.

Dendawijaya, Lukman. 2009. Manajemen Perbankan. Jakarta: Ghalia Indonesia.

Felope, Olufemi and Olubanje T. Ajilore. 2009. Working Capital Management and Corporate Profitability: Evindance From Panel Data Analysis of Selected Quoted Companies at Nigeria. Research Journal of Business Management, 3(3), pp: 73-84.

Ferry, M.G., and Jones, W.H. 1979. Determinants of financial structure: A new methodological approach. Journal of Finace,(3), pp: 101-119.

Fitzsimmons, J. R., Steffens, P., \& Douglas, E. J., 2005. Growth and Profitability in small and medium sized Australian firms. AGSE Entrepreneurship Exchange.

Gamze Vural. Sokmen, Ahmet Gokhan. Cetenak dan Emin Huseyin. 2012. Affects of working Capital Management on Firm's Perfomence Evidence from Turkey. International Journal of Economic and Financial Issues. 2 (4). pp. 488-495.

Jama'an. 2008. Pengaruh Mekanisme Corporate Governance dan Kualitas Kantor Akuntan Publik Terhadap Intergritas Informasi Laporan Keuangan. Jurnal Program Pascasarjana Universitas Diponegoro, 8(2), hal: 4.

Khaldun, Faiz. 2017. Pengaruh Pertumbuhan Aset, Pertumbuhan Penjualan, Profitabilitas dan Umur Perusahaan Terhadap Struktur Modal Pada Perusahaan Properti Tahun 2011-2015. Skripsi. Jakarta: Fakultas Ekonomi dan Bisnis Universitas Islam Negeri Syarif Hidayatullah. 
Kusumajaya, Dewa Kadek Oka. 2011. Pengaruh Struktur Modal dan Pertumbuhan Perusahaan terhadap Profitabilitas dan Nilai Perusahaan pada Perusahaan Manufaktur di Bursa Efek Indonesia. Skripsi. Denpasar: Fakultas Ekonomi dan Bisnis Universitas Udayana.

Lestari, Vivi dan Dian Satriya. 2014. Pengaruh Perputaran Modal Kerja Terhadap Profitabilitas Perusahaan. Skripsi. Denpasar: Fakultas Ekonomi dan Bisnis Universitas Udayana.

Leunupun, Pieter. 2003. Profitabilitas ekuitas dan beberapa faktor yang mempengaruhinya (studi pada beberepa KUD di kota ambon). Jurnalakuntansi \& keuangan, 5(2), hal: 133-149.

Marchyta, Nony Kezia., dan Astuti, Dewi. 2015. Pengaruh Struktur Modal dan Karakteristik Perusahaan terhadap Profitabilitas dan Nilai Perusahaan. Jurnal FINESTA, 3 (1), hal 13-15.

Munawir, S. 2012. Analisa Laporan Keuangan. Yogyakarta: Liberty.

Narware, P. C. N.d. Working Capital And Profitability - An Empirical Analysis. http://www.icwai.org/icwai/iknowledgebank/fm46.pdf. diakses 7 juni 2016

Nopiana, Yuli. 2015. Pengaruh Tingkat Perputaran Modal Kerja, Perputaran Kas, Perputaran Piutang, Pertumbuhan Jumlah Nasabah dan Jumlah Karyawan terhadap Profitabilitas Koperasi Simpan Pinjam (KSP) Di Kabupaten Buleleng.Journal Akuntansi Universitas Pendidikan Ganesha, 3(1), hal: 58 .

Pierre. 2010. The Relationship Between Working Capital Manajement and Profitability For South African Listed Industrial Firms. The Business Review. Cambridge. 15(1). Pp. 193-198.

Prihadi, Toto. 2012. Memahami Laporan Keuangan Sesuai IFRS dan PSAK. Jakarta: PPM.

Putra, Krisnanda. 2009. Faktor-Faktor yang Mempengaruhi Struktur Modal Perusahaan Manufaktur di Indonesia. Jurnal Akuntansi Fakultas Ekonomi Universitas Muhammadiyah, 3(2), hal: 7.

Raheman, Abdul and Mohamed Nasr. 2007. Working Capital Management And Profitability - Case Of Pakistani Firms. Journalof Business Research Papers, 3(1), hal: $279-300$.

Rajesh, Reddy. 2011. Impact of Working Capital Management on Firm's Profitability. Journalof Finance and Management, 3(1), hal: 151 -158.

Riyanto, Bambang. 2001. Dasar-Dasar Pembelajaran Perusahaan. Edisi Keempat Cetakan Keenam. Yogyakarta: BPFE. 
Santoso, Clairenr. 2013. Perputaran Modal Kerja dan Perputaran Piutang Pengaruhnya terhadap Profitabilitas pada PT. Pegadaian. Jurnal Akuntansi, 1(4), hal: 7-8.

Saraswathi, Ida Ayu Anggawulan. 2016. Pengaruh Risiko Bisnis, Pertumbuhan Perusahaan dan Struktur Modal Terhadap Profitabilitas Serta Nilai Perusahaan Manufaktur. E-Jurnal Ekonomi dan Bisnis Universitas Udayana, 5(6), hal: 20.

Sitio, Arifin, dan Tamba, Halomoan. 2001. Koperasi: Teori dan Praktik. Jakarta: Erlangga.

Sugiyono. 2016. Metode Penelitian Bisnis. Cetakan 18. Bandung: CV. Alfabeta.

Sunarto dan Agus Prasetyo Budi. 2009. Pengaruh Leverage, Ukuran dan Pertumbuhan Perusahaan terhadap Profitabilitas. Jurnal TEMA, Vol 6(1): Hal.86-103.

Susan, F 2011.Working Capital Management on Firm's Profitability.Journalof Finance and Management,7(4), hal: 159.

Tesha, R 2012.Impact of Working Capital Management on Firm's Profitability.Journalof Finance and Management, 9 (3), hal: 175.

Undang-Undang 1945 Bab XIV Pasal 33 Ayat (1).

Undang-Undang Republik Indonesia No. 25 Tahun 1992. Tentang Perkoperasian.

Utama, Made Suyana. 2011. Aplikasi Analisis Kuantitatif edisi kelima. Denpasar. Sastra Utama. 